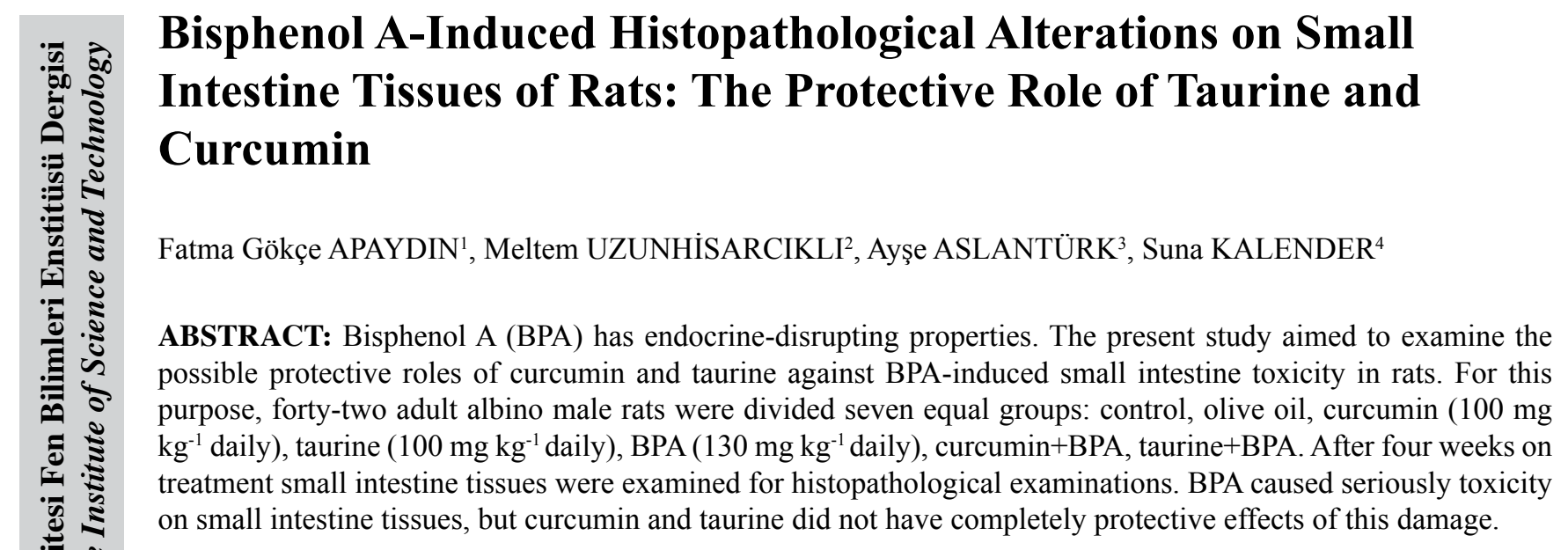

Keywords: Bisphenol A, curcumin, histopathology, small intestine, taurine

\title{
Bisfenol A’nın Sıçan İnce Bağırsak Dokusunda Oluşturduğu Histopatolojik Değişiklikler Üzerine Taurin ve Kurkumin'in Koruyucu Rolü
}

ÖZET: Bisfenol A (BPA) endokrin bozucu özelliğe sahip bir kimyasaldır. Bu çalışmanın amacı, BPA'nın sıçan ince bağırsak dokusunda meydana getirdiği toksik etkiye karşı taurin ve kurkuminin olası koruyucu etkilerini incelemektir. Bu amaçla, kırk iki erkek albino sıçan yedi eşit gruba ayrılmıştır bunlar: kontrol, yağ, taurin(100 mg $\mathrm{kg}^{-1}$ vücut ağırlığı), kurkumin(100 mg kg-1 vücut ağırlığı), bisfenol A (130 mg kg ${ }^{-1}$ vücut ağırlığı), BPA+taurin ve BPA+kurkumin. Uygulamadan dört hafta sonra ince bağırsak dokuları histopatolojik incelemeler için alınmıştır. BPA ince bağırsak dokusunda önemli histopatolojik değişimlere sebep olmuştur, taurin ve kurkumin ise tamamen koruyucu etki oluşturmamıştır.

Anahtar Kelimeler: Bisfenol A, histopatoloji, ince bağırsak, kurkumin, taurin

Fatma Gökçe APAYDIN (0000-0002-2771-7488), Gazi Üniversitesi, Fen Fakültesi, Biyoloji, Ankara, Türkiye

Meltem UZUNHISARCIKLI (0000-0003-1265-8347), Gazi Üniversitesi, Sağlık Hizmetleri Meslek Yüksekokulu, Yaşlı Bakımı, Ankara, Türkiye Ayşe ASLANTÜRK (0000-0002-4737-702X), Gazi Üniversitesi, Sağlık Hizmetleri Meslek Yüksekokulu, Patoloji Laboratuvar Teknikleri, Ankara, Türkiye

4 Suna KALENDER (0000-0002-9654-1287), Gazi Üniversitesi, Gazi Eğitim Fakültesi, Fen Bilgisi Eğitimi, Ankara, Türkiye Sorumlu yazar/Corresponding Author: Fatma Gökçe APAYDIN, fguzun@ gazi.edu.tr 


\section{INTRODUCTION}

Bisphenol A (BPA) is found in food can liners, plastic containers, electronic products, epoxy resins, and bottles, and is exposed by the breakdown of chemical bonds (Ortiz-Villanueva et al., 2017; Tarapore et al., 2017). BPA exposure may cause several diseases like obesity, diabetes, organ dysfunctions (Tarapore et al., 2017). BPA exposure may effect different organs like testes via inhibition of testicular spermatogenesis (Tarapore et al., 2017). Human exposed to BPA through the food chain because BPA found in several food containers (El-Missiry et al., 2014). Besides, BPA causes nephrotoxicity, hepatoxicity, neurotoxicity in experimental animals (Mahmoudi et al., 2015; Zhou et al., 2017).

In toxicological studies, evaluation of organ toxicity is an important criterion. It is well documented that many xenobiotic may induce tissue damage related to oxidative stress in animals (Apaydin et al., 2017, Kalender et al., 2014). Increased lipid peroxidation (LPO) in various tissues may be one of the molecular mechanisms involved in chemicals induced toxicity (Verhagen et al., 2006).

Various researchers have been showed the positive protective effect of various natural and synthetic materials by the antioxidant properties on the BPAinduced toxicity. Because antioxidant supplementation may be important to reduce the toxicity of BPA (Mahmoudi et al., 2015).

Curcumin, the major polyphenolic component of turmeric (Curcuma longa) rhizomes, a member of the ginger family (Zingiberaceae). Curcumin has a wide spectrum of therapeutic agent and it has been shown antioxidant effects, anti-inflammatory, anti-cancer and anti-cholinesterase activities (Akinyemi et al., 2017). Additionally, it has been used for antidepressant properties (Sanmukhani et al., 2014).

Taurine, a sulfur-containing semi-essential amino acid, is found in high concentrations in mammalian plasma and cells. It participant in a number of different physiologic and biologic processes in different tissues (Feng et al., 2017). It has been reported that taurine found in intracellular place approximately 20-50 micromolar concentrations (Learn et al., 1990). In addition, taurine endogenously synthesized from cysteine (Murakami, 2017). It has been reported that taurine has been shown as a reno-protective agent (Feng et al., 2017).
For this reason, in this study we aim to possible protective role of curcumin or taurine treatment on small intestine tissues of rats against BPA.

\section{MATERIALS AND METHODS}

\section{Chemicals}

Taurin ( $\geq 99 \%$ purity) and Curcumin (from Curcuma longa (Turmeric)) were purchased from Sigma. Bisphenol A ( $\geq 99 \%$ purity) was provided by Aldrich.

\section{Animals and Experimental Design}

Adult male albino rats (weighing 250-300g) were obtained from GUDAM and were housed in cages, at room temperature $20 \pm 2^{\circ} \mathrm{C}$, relative humidity $40 \%$, and $12 \mathrm{~h} \mathrm{light/dark} \mathrm{cycle.} \mathrm{Food} \mathrm{(pellet} \mathrm{rat} \mathrm{chow)} \mathrm{and}$ water available ad libitum. Experimental studies were confirmed by University of Gazi Animal Ethics Committee (G.U.ET-14.075). After acclimatization, animals were divided seven groups $(n=6)$ categorized as follows:

Group 1 (control group): received distilled water (1.0 $\mathrm{ml} \mathrm{kg}^{-1}$ bw daily).

Group 2 (olive oil group): received olive oil (1.0 $\mathrm{ml} \mathrm{kg}{ }^{-1}$ bw daily).

Group 3 (curcumin group): received curcumin (100 $\mathrm{mg} \mathrm{kg}^{-1}$ bw daily in olive oil).

Group 4 (taurine group): received taurine (100 mg $\mathrm{kg}^{-1}$ bw daily in distilled water).

Group 5 (BPA group): received bisphenol A (130 $\mathrm{mg} \mathrm{kg}^{-1}$ bw daily in olive oil).

Group 6 (BPA + curcumin group): received curcumin and bisphenol A (100 mg kg ${ }^{-1}$ bw daily +130 $\mathrm{mg} \mathrm{kg}^{-1}$ bw daily, respectively).

Group 7 (BPA + taurine group): received taurine + bisphenol A (100 mg kg${ }^{-1}$ bw daily $+130 \mathrm{mg} \mathrm{kg}^{-1} \mathrm{bw}$ daily, respectively).

Both solutions were administrated via gavage during 28 days. BPA and solutions were freshly prepared. After the treatment period, animals were sacrificed under the anesthesia and small intestine tissues removed quickly. 


\section{Histopathological Examination}

For light microscopy, small intestine samples were fixed in $10 \%$ neutral formalin and processed for paraffin sections of 6-7 $\mu$ thickness. Sections were stained with hematoxylin and eosin for routine histological investigations. Then the tissues were evaluated under a light microscope (Olympus BX51, Tokyo, Japan) and photographed with a camera (Olympus E-330, Olympus Optical Co., Ltd., Japan). Ten slides were prepared from each small intestine tissues.

\section{RESULTS AND DISCUSSION}

In our study histopathological examination of rat small intestine were investigated using light microscope. Histological examinations of small intestine tissues of the control, olive oil, taurine and curcumin-treated rats indicated normal arrangement of villus, with no histological alterations in the small intestine of the four groups (Figure 1).

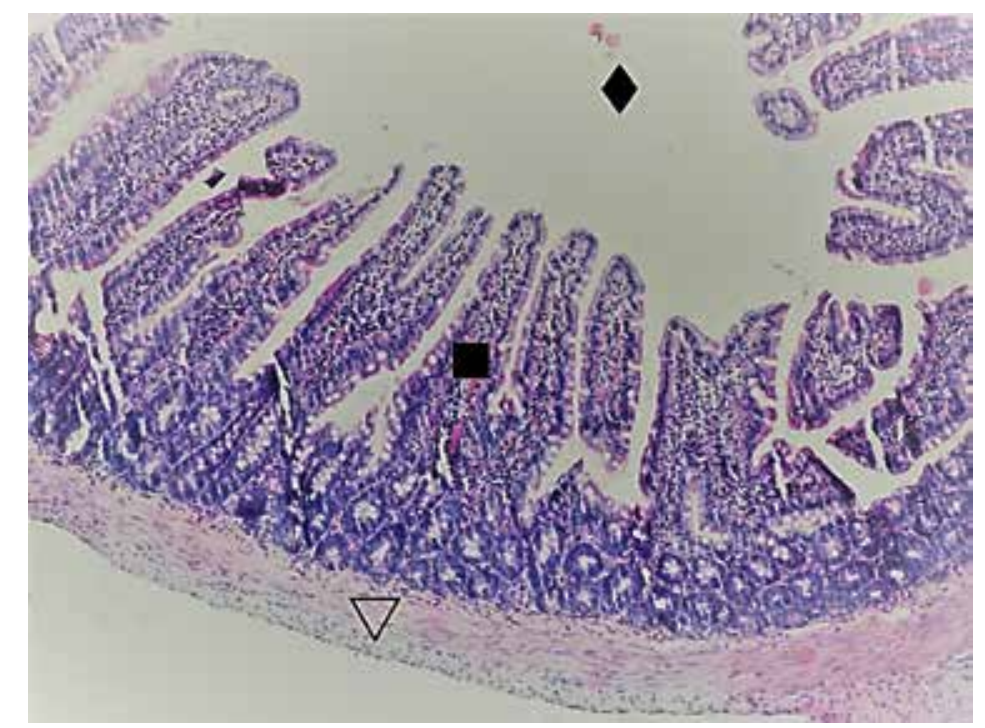

Figure 1. Small intestine sections of control rats, H\&E. $\$$ Lumen, $\mathbf{\square}$ : villi, $\triangle$ : muscle X100

The small intestine of BPA-treated animals, microscopic examinations showed that BPA induced necrosis and edema (Figure 2). Curcumin plus BPA treated groups we show that some necrotic changes and degenerative changes in villus (Figures 3 ). In taurine plus BPA treated group we show that some degenerative changes in villus (Figures 4).

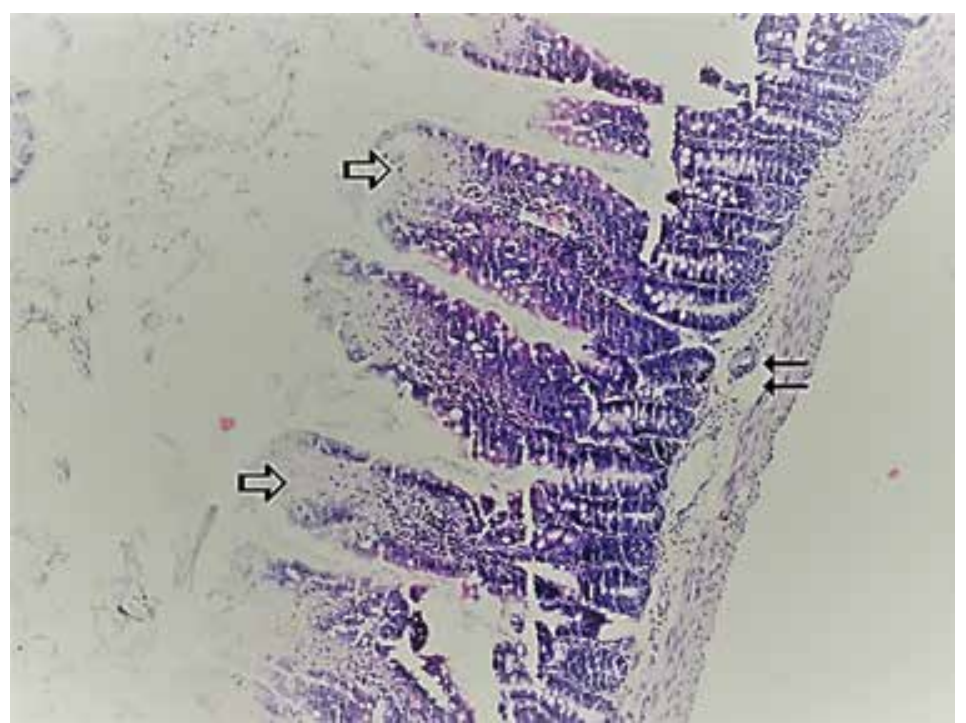

Figure 2. Small intestine sections of BPA-treated rats, H\&E. $\Rightarrow$ : necrosis, $\rightrightarrows$ : edema. x200 


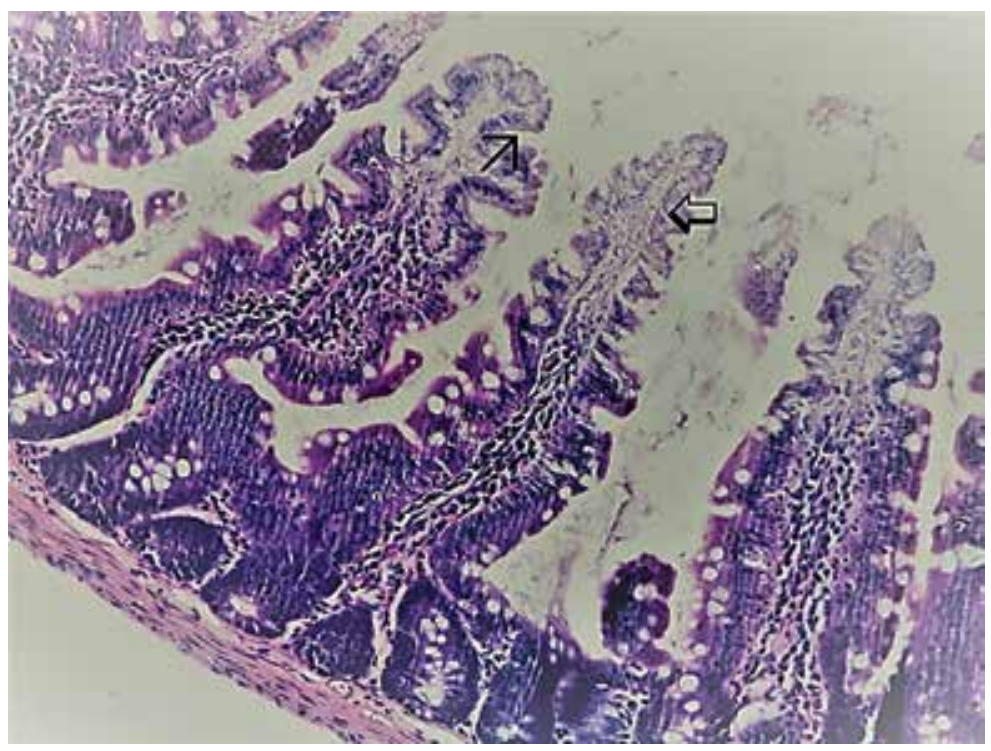

Figure 3. Small intestine sections of Bisphenol A+Curcumin treated rats, H\&E. $\Rightarrow$ : necrosis, $\rightarrow$ :degenerative changes in villus $\times 100$

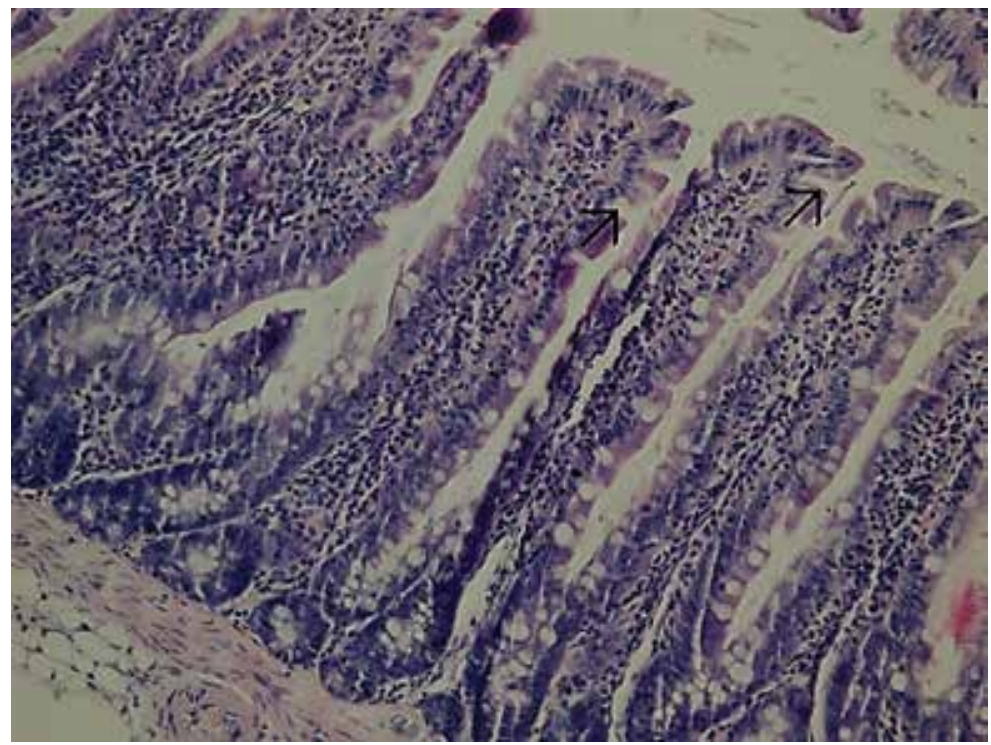

Figure 4. Small intestine sections of Bisphenol A+Taurine treated rats, H\&E. $\rightarrow$ : degenerative changes in villus x100

It is known that, BPA is a xenoestrogen compound that has adverse effect on the especially reproductive organs (Eid et al., 2015). In the last years, there are increasing investigations about that BPA, but still human exposed to BPA analogues in the environment. It has been reported that BPA caused pathological effects different tissues like hippocampus, liver, kidney (Mahmoudi et al., 2015; Zhou et al., 2017). Although there is many study about general toxic effects of BPA, there isn't enough study about small intestine toxicity of BPA. In the present study, we examined that the effects of BPA exposure on small intestine histological structure. The oral $\mathrm{LD}_{50}$ of BPA for male rats is 3250 $\mathrm{mg} / \mathrm{kg}$ body weight (Michalowicz, 2014). In the present study, BPA was given at $1 / 25$ of oral $\mathrm{LD}_{50}$ and none of the rats died during the experimental period.

Shirpoor et al reported that ethanol-induced small intestine damage in rats via villus height changes, crypt depth and muscular layer thickness related to oxidative stress (Shirpoor et al., 2016). Similarly, in our study we showed that several pathological changes like necrosis, degenerative changes in villus in small intestine tissues. It may be due to oxidative damages of BPA on cells. Because it has been reported that BPA caused oxidative damage on cells in many studies (Mahmoudi et al., 
2015). For example, Hassan et al., showed that BPA treatment leads to cell rupture and membrane damage of human erythrocytes which may related to oxidative stress (Hassan et al., 2012).

The cells have various defense mechanisms against oxidative stress, including enzymatic antioxidants and non-enzymatic antioxidants that protect the cell and organs from negative effects of reactive oxygen species (Apaydın et al., 2017).

Several studies have demonstrated curcumin's varied biological activities such as anti-diabetic, antioxidant, anti-coagulant and anti-cancer activity in various cells (Zhang et al., 2017). Similarly, taurine has therapeutic affect in mammalian cells include, antioxidant effect (Wang et al., 2015).

\section{REFERENCES}

Akinyemi AJ, Oboh G, Fadaka AO, Olatunji BP, Akomolafe S, 2017. Curcumin administration suppress acetylcholinesterase gene expression in cadmium treated rats. Neurotoxicology, 62: 75-79.

Apaydın FG, Bas H, Kalender S, Kalender Y, 2017. Bendiocarb induced histopathological and biochemical alterations in rat liver and preventive role of vitamins $\mathrm{C}$ and E. Environmental Toxicology and Pharmacology, 49: 148-155.

Eid JI, Eissa SM, El-Ghor, AA, 2015. Bispheol A induces oxidative stress and DNA damage in hepatic tissue of female rat offspring. The Journal of Basic and Applied Zoology, 71:1019.

El-Missiry MA, Othman AI, Al-Abdan, MA, Sayed, AA, 2014. Melatonin ameliorates oxidative stress, modulates death receptor pathway proteins, and protects the rat cerebrum against Bisphenol-A-induced apoptosis. Journal of the Neurological Sciences, 347: 251-256.

Feng Y, Sun F, Gao Y, Yang J, Wu G, Lin S, Hu J, 2017. Taurine decreased uric acid levels in hyperuricemic rats and alleviated kidney injury. Biochemical and Biophysical Research Communications, 489: 312-318.

Hassan ZK, Elobeid MA, Virk P, Omer SA, El Amin M, Daghestani MH, AlOyan EM, 2012. Bisphenol A induces hepatotoxicity through oxidative stress in rat model. Oxidative Medicine and Cellular Longevity, 2012: 194829.

Kalender S, Apaydın FG, Demir F, Bas H, 2014. Lead nitrate induced oxidative stress in brain tissues of rats: protective effect of sodium selenite. Gazi University Journal of Science, 27(3): 883-889.

Learn DB, Fried VA, Thomas EL, 1990. Taurine and hypotaurine content of human leukocytes. Journal of Leukocyte Biology, 48: $174-182$.

Mahmoudi A, Ghorbel H, Bouallegui Z, Marrekchi R, Isoda H, Sayadi S, 2015. Oleuropein and hydroxytyrosol protect from bisphenol A effects in livers and kidneys of lactating mother rats and their pups. Experimental and Toxicologic Pathology, 67: 413-425.

\section{CONSLUSION}

In conclusion, as we known that preventive effects of taurine and curcumin possibly are due to their antioxidant properties on different tissues. However, in this study we haven't show completely protection. It may be related to their doses that used in this study. They may be lower or higher doses against of BPA. However, we show fever histopathological changes in antioxidant supplementation groups than only BPA treated group.

\section{Conflict of Interest}

The authors declare no conflict of interests.

Michalowicz J, 2014. Bisphenol A-Sources, toxicity and biotransformation. Environmental Toxicology and Pharmacology, 27: 738-758.

Murakami S, 2017. The physiological and pathophysiological roles of taurine in adipose tissue in relation to obesity. Life Sciences, 186: 80-86.

Ortiz-Villanueva E, Navarro-Martín L, Jaumot J, Benavente F, SanzNebot V, Pina, B, Tauler R, 2017. Metabolic disruption of zebrafish (Danio rerio) embryos by bisphenol A. An integrated metabolomic and transcriptomic approach. Environmental Pollution, 231: 22-36.

Sanmukhani J, Satodia V, Trivedi J, Patel T, Tiwari D, Panchal B, Goel A, Tripathi CB, 2014. Efficacy and safety of curcumin in major depressive disorder: a randomized controlled trial. Phytotherapy Research, 28: 579-585.

Shirpoor A, Barmaki H, Ansari MK, Ikhanizadeh B, Barmaki H, 2016. Protective effect of vitamin E against ethanolinduced small intestine damage in rats. Biomedicine \& Pharmacotherapy, 78: 150-155.

Tarapore P, Hennesy M, Song D, Ying J, Outang B, Govindarajah V, Leung Y, Ho S, 2017. High butter-fat diet and bisphenol A additively impair male ratspermatogenesis. Reproductive Toxicology, 68: 191-199.

Verhagen H, Buijsse B, Jansen E, Bueno-de-Mesquita B, 2006. The state of antioxidant affairs, Nutrition Today, 41(6): 244-250.

Wang Y, Yuan J, Lu W, Li B, Xu D, 2015. Taurine zinc solid dispersions attenuate doxorubicin-induced hepatotoxicity and cardiotoxicity in rats. Toxicology and Applied Pharmacology, 289: $1-11$.

Zhang H, Huang X, Sun J, Yamamoto A, Gao Y, 2017. Enhanced pulmonary bioavailability of curcumin by some common excipients and relative therapeutic effects on sepsis-induced acute lung injury in rats. Journal of Drug Delivery Science and Technology, 41: 231-238.

Zhou Y, Wang Z, Xia M, Zhuang S, Gong X, Pan J, Li C, Fan R, Pang Q, Lu S, 2017. Neurotoxicity of low bisphenol A (BPA) exposure for young male mice: Implications for children exposed to environmental levels of BPA. Environmental Pollution, 229: 40-48. 